\title{
In Vitro Propagation and Post-in Vitro Establishment of Bulblets of Lilium japonicum Thunb.
}

\author{
Yoshiji Niimi \\ Faculty of Agriculture, Niigata University, Niigata 950-21
}

\begin{abstract}
Summary
Lilium japonicum growing in the experimental field were collected in early May and segments of their scales, leaves and stems of the plants were cultured in vitro on a basal medium consisting of Murashige and Skoog's inorganic salts (1962) supplemented with several organic nutrients. Young leaf-segments were a suitable source for propagation, because they were least contaminated and almost had the same capacity as scale seg. ments for bulblet regeneration. Bulblets were proliferated by culturing whole scales or segments on the basal medium supplemented with $0.1 \mathrm{mg} \cdot \mathrm{liter}^{-1} \mathrm{NAA}$ and 0.01 $\mathrm{mg} \cdot \mathrm{liter}^{-1} \mathrm{BA}$. A cold treatment at $4{ }^{\circ} \mathrm{C}$ for more than 12 weeks broke the dormancy of in vitro cultured bulblets. In vitro light conditoin affected both post-in vitro bulblet-rot infection and plant growth in soil. The bulblets incubated in the dark were more susceptible to soil-born organisms than were those incubated in the light. Nearly all the bulblets of more than $400 \mathrm{mg}$ in weight grew into plants with elongated axes (epigeous type plant; ETP). The ETP plantlets required at least 2 years' cultivation before they flowered.
\end{abstract}

\section{Introduction}

Lilizm japonicum Thunb., 'Sasa-yuri' is indigenous to the hills and low mountains of the central and western districts of Honshu. Shikoku, and Kyushu, Japan (Shimizu, 1987). Reductions in population and limited distribution have led $L$. japonicum close to extinction. In addition, it has considerable potential as an ornamental crop because of its trumpet-shaped beautiful flowers en dowed with good pink color and pleasant fragrance. Some growers have attempted to produce bulbs commercially through seed and scale propagation, but an appropriate commercial method of proliferating the bulbs has not been established. This paper describes the aseptic cultures, in vitro proliferation, and post-in vitro establishment of $L$.

Received for publication 8 July 1994.

This work was supported by Grant-in-Aid for Science Research (no. 6150029) from the Ministry of Education. Parts of this paper were presented at the 1990 Spring and 1993 Autumn meetings of the Japanese Society for Horticultural Science and the 24th International Horticultural Congress in Japan. 1994. japonicum bulblets.

\section{Materials and Methods}

\section{Experiment 1. Establishment of aseptic cultures}

A basal medium consisted of Murashige and Skoog's inorganic salts (1962), $2 \mathrm{mg} \cdot \mathrm{liter}^{-1} \mathrm{gly}$ cine, $100 \mathrm{mg} \cdot$ liter $^{-1}$ myoinositol, $0.1 \mathrm{mg} \cdot$ liter $^{-1}$ thiamine hydrochloride, $0.5 \mathrm{mg} \cdot$ liter $^{-1}$ nicotinic acid, $0.5 \mathrm{mg} \cdot$ liter $^{-1}$ pyridoxine hydrochloride, $5 \%$ sucrose, $0.7 \%$ Difco Bacto agar, and, except where otherwise stated, $1 \mathrm{mg} \cdot$ liter $^{-1} \mathrm{NAA}$ and 0.1 mg $\cdot$ liter $^{-1}$ BA (Niimi and Onozawa, 1979).

Three plants, having stems about $15 \mathrm{~cm}$ in length, were harvested from the experimental field in early May. Young growing leaves, terminal portion of stem (about $10 \mathrm{~cm}$ long), and a bulb were separated from each plant, washed with soap, and then rinsed thoroughly with tap water.

\section{1) Sterilizaton}

Leaves and stems were sterilized with $70 \%$ ethanol, rinsed with tap water, swirled for $5 \mathrm{~min}$ utes in $0.6 \%$ sodium hypochlorite. Bulbs were im 
mersed in aqueous $0.1 \%$ Benlate for 30 minutes after removal of damaged outer-scales.

Healthy scales separated from the bulbs were sterilized with the same methods as used for leaves and stems, except that the scales were swirled for 20 minutes in $2 \%$ sodium hypochlorite.

Finally, each organ was rinsed three times in sterile water.

\section{2) Preparation of explants and inoculation}

(1) Scale explants: A scale segment, about $1 \mathrm{~cm}^{2}$, was excised from the lower portion of each scale and placed with the abaxial side down on the 20 $\mathrm{ml}$ basal medium in a test tube $(18 \times 180 \mathrm{~mm})$.

(2) Leaf explants: A $3 \sim 5 \mathrm{~mm}$ long proximal regions including petiole was cut away from a young leaf, and then three leaf-strips, $5 \mathrm{~mm}$ in length, were excised transversely from the basal portion. They were designated as L-I, L-II, and L-III and placed, abaxial side down, on the $20 \mathrm{ml}$ basal medium in a $50-\mathrm{ml}$ Erlenmeyer flask.

In an additional experiment, five 3 -mm leafstrips from the proximal portion of leaves (designated as GL-I) and five other strips from the midportion of leaves (designated as GL-II) were excised and cultured on the basal medium containing $\mathrm{BA}$ at concentrations of $0.005,0.01$ and 0.05 $\mathrm{mg} \cdot$ liter $^{-1}$ in combination with $0.5 \mathrm{mg} \cdot$ liter $^{-1}$ NAA (Table 2).

(3) Stem explants: Ten stem-segments, $5 \mathrm{~mm}$ long, were prepared by transversely cutting the terminal portion of a stem; each segment was placed with the basal cut end, surface down, on the basal medium in a test-tube $(18 \times 180 \mathrm{~mm})$.

\section{3) Culture conditions}

All explants were kept in the dark at $24 \pm 1{ }^{\circ} \mathrm{C}$ for 90 days at the end of which the number of bulblets per explant, fresh weight of bulblets excluding roots, and the percentage of contamination were determined.

\section{Experiment 2. Proliferation of bulblets by culturing whole scales and scale segments}

Scales, excluding a few inner small scales, were excised aseptically from bulblets that had been cultured on the basal medium containing 0.05 $\mathrm{mg} \cdot$ liter $^{-1}$ NAA for more than 12 weeks at $24 \pm 1$ ${ }^{\circ} \mathrm{C}$ in the dark.

1) Whole scale culture: Five randomly selected. scales were placed, abaxial side down, in a $50-\mathrm{ml}$ Erlenmeyer flask containing $20 \mathrm{ml}$ of the basal medium supplemented with different concentrations of NAA and BA. Eight flasks per treatment were kept for 12 weeks under continuous white fluorescent lamps giving about 1000 to $1200 \mathrm{~lx}$ at the culture level (Table 3 ).

2) Scale segment culture: Scales were cut transversely into two (basal and terminal portions) or three (basal, middle and terminal portions). Five comparable segments were placed, abaxial side down, in a 50-ml Erlenmeyer flask containing 20 $\mathrm{ml}$ of the basal medium supplemented with 0.1 $\mathrm{mg} \cdot \mathrm{liter}^{-1} \mathrm{NAA}$ and $0.01 \mathrm{mg} \cdot \mathrm{liter}^{-1} \mathrm{BA}$. The 13 to 15 flasks per treatment were kept in the dark for 12 weeks (Table 4).

In both experiments, the number of bulblets per explant and weight of fresh bulblets excluding roots were determined after 12 weeks of culture.

Experiment 3. Establishment of bulblets in soil

\section{1) Low temperature treatment and transplanting to soil}

Bulblets that had been cultured for more than 3 months on the basal medium containing 0.1 mg $\cdot$ liter $^{-1}$ NAA and $0.01 \mathrm{mg} \cdot \mathrm{liter}^{-1} \mathrm{BA}$ at $24 \pm$ $1^{\circ} \mathrm{C}$ in the dark were washed with tap water. After cutting the roots at the base, bulblets weighing 100 to $200 \mathrm{mg}$, were mixed with moist vermiculite, placed in polyethylene bags $(0.03 \mathrm{~mm}$ in thickness), and stored at $4{ }^{\circ} \mathrm{C}$ for $0,2,4,6,8$, 10,12 , and 14 weeks. After the cold treatment, 10 bulblets, with 5 replicates for each treatment, were transplanted, $1 \mathrm{~cm}$ deep, in a plastic tray $(50$ $\times 35 \times 7.5 \mathrm{~cm})$ containing sandy-loam and leaf mold mix $(1: 1 \mathrm{v} / \mathrm{v})$. The trays were transferred to a glasshouse, where the night $\left(10 \sim 20{ }^{\circ} \mathrm{C}\right)$ and day $\left(15 \sim 30^{\circ} \mathrm{C}\right)$ temperatures fluctuated depending on the weather. The data of leaf emergence was recorded every 3 day for 45 days. All bulblets were gathered 13 weeks after transplanting to determine the number of surviving bulblets, their fresh weight and that of roots (Fig. 1, Table 5).

\section{2) Post-in vitro growth of bulblets in soil}

It was tested whether in vitro dark- and lightconditions affect the post-in vitro growth of bulblets in soil. Bulblets that had been cultured on the basal medium containing $0.1 \mathrm{mg} \cdot \mathrm{liter}^{-1} \mathrm{NAA}$ and 
$0.01 \mathrm{mg} \cdot$ liter $^{-1} \mathrm{BA}$ in the dark or light (about $150 \sim 300 \mathrm{~lx}$ ) were treated as in Experiment 3-1). After being stored at $4{ }^{\circ} \mathrm{C}$ for 12 weeks, each was classified according to its weight and planted $1 \mathrm{~cm}$ deep in a plastic tray (Table 6). The bulblets were grown for 8 weeks under the same condition as in Experiment 3-1). Then, the numbers of rotten bulblets, surviving bulblets with growing leaves, and plant growth types (bolted plantlets without scaly leaves; epigeous type plant. ETP or unbolted plantlets only with scaly leaves; hypogeous type plant, HTP) (Matsuo et al., 1982) were counted.

\section{Results}

\section{Experiment 1. Establishment of aseptic cultures and determination of initial propagation- materials}

Scale-segments formed 3.1 bulblets per explant.
Leaf segments, of L-I and L-II, and stem-segments developed 2 to 2.4 bulblets per explant.

The average fresh weight of bulblets differed considerably; those developed on the leaf-segments were heavier and those from scale-segments were lightest.

No leaf-segments became contaminated, whereas 3 and $18 \%$ of the stem- and scale-segments, respectively, were contaminated (Table 1).

In an additional experiment (Table 2), leaf-segments or GL-I formed as many bulblets as those in scale-segments. However, GL-II formed no bulblets on the medium without BA, and $52 \%$ of the explants formed bulblets when they were cultured on the medium with $0.05 \mathrm{mg} \cdot$ liter $^{-1} \mathrm{BA}$ and 0.5 $\mathrm{mg} \cdot$ liter $^{-1}$ NAA.

Thus, it was found that GL-I and -II were the most suitable initial materials to establish aseptic tissue cultures of $L$. japonicum.

Table 1. In vitro bulblet-productivity of explants excised from different organs of mother bulbs of $L$. japonicum. \pm indicates standard error of the mean.

\begin{tabular}{lccccc}
\hline \hline Explants & $\begin{array}{l}\text { Number of } \\
\text { explants } \\
\text { cultured }\end{array}$ & $\begin{array}{l}\text { Number of } \\
\text { explants } \\
\text { forming } \\
\text { bulblets }\end{array}$ & $\begin{array}{l}\text { Number of } \\
\text { bulblets per } \\
\text { regenerated } \\
\text { explant }\end{array}$ & $\begin{array}{l}\text { Mean fresh } \\
\text { weight of } \\
\text { bulblets } \\
\text { (mg) }\end{array}$ & $\begin{array}{l}\text { Number of } \\
\text { explants } \\
\text { contaminated }\end{array}$ \\
\cline { 3 - 6 } & 33 & $25(76)$ & 3.1 & $39 \pm 6$ & $6(18)$ \\
$\begin{array}{l}\text { Scale segments } \\
\text { Leaf strips }\end{array}$ & 18 & $15(83)$ & 2.2 & $99 \pm 16$ & 0 \\
$\quad$ L- I & 18 & $13(72)$ & 2.0 & $104 \pm 15$ & 0 \\
L- II & 18 & $9(50)$ & 1.1 & $78 \pm 17$ & 0 \\
L- II & 33 & $27(82)$ & 2.4 & $55 \pm 7$ & $1(3)$ \\
Stem segments & & & & & \\
\hline
\end{tabular}

$\approx$ Figures in parenthesis represent $\%$ of explants with bulblets.

$y$ Figures in parenthesis represent $\%$ of explants contaminated.

Table 2. Bulblet formation in leaf segments of $L$. japonicum cultured in a basal medium containing NAA and $\mathrm{BA}$ at different concentrations. \pm indicates standard error of the mean.

\begin{tabular}{|c|c|c|c|c|c|c|}
\hline $\begin{array}{l}\text { NAA } \\
\text { (mg. }\end{array}$ & $\cdot$ liter $^{-1}$ ) & $\begin{array}{l}\text { Leaf } \\
\text { strips }\end{array}$ & $\begin{array}{l}\text { Number of } \\
\text { strips } \\
\text { cultured }\end{array}$ & $\begin{array}{l}\% \text { of strips } \\
\text { forming } \\
\text { bulblets }\end{array}$ & $\begin{array}{l}\text { Number of } \\
\text { bulblets per } \\
\text { cultured strip }\end{array}$ & $\begin{array}{l}\text { Mean fresh } \\
\text { weight of } \\
\text { bulblets } \\
\text { (mg) }\end{array}$ \\
\hline 0.5 & 0 & $\begin{array}{l}\mathrm{GL}^{-} \mathrm{I} \\
\mathrm{GL}-\mathrm{II}\end{array}$ & $\begin{array}{l}25 \\
25\end{array}$ & $\begin{array}{c}40 \pm 10 \\
0\end{array}$ & $\begin{array}{c}1.0 \pm 0.3 \\
0\end{array}$ & $\begin{array}{c}61 \pm 11 \\
0\end{array}$ \\
\hline 0.5 & 0.005 & $\begin{array}{l}\text { GL- I } \\
\text { GL- II }\end{array}$ & $\begin{array}{l}25 \\
25\end{array}$ & $\begin{array}{l}80 \pm 11 \\
16 \pm 7\end{array}$ & $\begin{array}{l}3.2 \pm 0.5 \\
0.5 \pm 0.2\end{array}$ & $\begin{array}{l}60 \pm 6 \\
16 \pm 2\end{array}$ \\
\hline 0.5 & 0.01 & $\begin{array}{l}\text { GL- I } \\
\text { GL- II }\end{array}$ & $\begin{array}{l}25 \\
25\end{array}$ & $\begin{array}{r}60 \pm 10 \\
8 \pm 7\end{array}$ & $\begin{array}{l}2.1 \pm 0.4 \\
0.3 \pm 0.2\end{array}$ & $\begin{array}{l}78 \pm 12 \\
37 \pm 13\end{array}$ \\
\hline 0.5 & 0.05 & $\begin{array}{l}\mathrm{GL}-\mathrm{I} \\
\mathrm{GL}-\mathrm{II}\end{array}$ & $\begin{array}{l}25 \\
25\end{array}$ & $\begin{array}{l}84 \pm 10 \\
52 \pm 15\end{array}$ & $\begin{array}{l}2.6 \pm 0.5 \\
1.6 \pm 0.4\end{array}$ & $\begin{array}{r}100 \pm 12 \\
60 \pm 7\end{array}$ \\
\hline
\end{tabular}


Experiment 2. Proliferation of bulblets through bulbscale cultures

Of excised scales incubated on the basal medium without growth regulators, $98 \%$ formed 1.8 bulblets per explant. The addition of NAA and BA at different concentrations to the basal medium had little effect on increasing the number of bulblets. The fresh weight of bulblets increased with the increasing concentration of NAA, whereas BA had little effect on increasing the weight (Table 3 ).

Culturing bi- or tri-sectioned scale-segments on the basal medium containing $0.1 \mathrm{mg}^{-l i t e \mathrm{r}^{-1}} \mathrm{NAA}$ and $0.01 \mathrm{mg} \cdot \mathrm{liter}^{-1} \mathrm{BA}$, the basal segments produced more than 2.2 bulblets, whereas the middle and terminal segments scarcely formed bulblets
(Table 4). Thus, the method of culturing bi- and tri-scale-sections had little effect on increasing the bulblet numbers.

\section{Experiment 3. Establishment of bulblets in soil}

Leaf emergence from chilled bulblets depended on the duration of the cold treatment (Fig. 1). None of the control bulblets kept at $25{ }^{\circ} \mathrm{C}$ sprouted during the 45-day experimental period, whereas bulblets chilled for more than 12 weeks sprouted in 15 days after transplanting. Bulblets chilled for less than 8 weeks sprouted later and produced fewer new leaves.

The duration of the cold treatment affected the rate of surviving bulblets and plant growth in the soil (Table 5). All bulblets chilled for more than

Table 3. Effect of NAA and BA concentrations on bulblet formation in the cultures of bulbscales isolated from in vitro axenic developing bulbs. \pm indicates standard error of the mean.

\begin{tabular}{|c|c|c|c|c|c|c|c|c|c|}
\hline \multirow{2}{*}{\multicolumn{2}{|c|}{$\underset{\left(\mathrm{mg} \cdot \text { liter }^{-1}\right)}{\mathrm{NAA}}$}} & \multirow{2}{*}{$\begin{array}{l}\text { \%of scales } \\
\text { with } \\
\text { bulblets }\end{array}$} & \multirow{2}{*}{$\begin{array}{l}\text { Number of } \\
\text { bulblets per } \\
\text { regenerating } \\
\text { scale }\end{array}$} & \multirow{2}{*}{$\begin{array}{l}\text { Mean fresh } \\
\text { weight of } \\
\text { bulblets } \\
\text { (mg) }\end{array}$} & \multirow{2}{*}{$\underset{10 \sim}{49 \mathrm{mg}}$} & \multicolumn{4}{|c|}{ Weight classes of bulblets (\%) } \\
\hline & & & & & & $\begin{array}{l}50- \\
99 \mathrm{mg}\end{array}$ & $\begin{array}{l}100- \\
149 \mathrm{mg}\end{array}$ & $\begin{array}{l}150 \sim \\
199 \mathrm{mg}\end{array}$ & $\begin{array}{l}\text { Above } \\
199 \mathrm{mg}\end{array}$ \\
\hline 0 & 0 & $98 \pm 2$ & $1.9 \pm 0.2$ & $47 \pm 5$ & 66 & 23 & 7 & 1 & 3 \\
\hline 0.01 & 0 & $98 \pm 2$ & $2.3 \pm 0.2$ & $47 \pm 4$ & 67 & 23 & 9 & 0 & 0 \\
\hline 0.01 & 0.005 & 100 & $2.5 \pm 0.2$ & $41 \pm 3$ & 72 & 25 & 3 & 0 & 0 \\
\hline 0.05 & 0 & 100 & $2.8 \pm 0.2$ & $55 \pm 4$ & 53 & 32 & 11 & 4 & 0 \\
\hline 0.05 & 0.01 & $95 \pm 3$ & $2.3 \pm 0.2$ & $60 \pm 6$ & 58 & 28 & 6 & 6 & 2 \\
\hline 0.1 & 0 & $98 \pm 2$ & $2.4 \pm 0.2$ & $61 \pm 4$ & 49 & 38 & 9 & 3 & 1 \\
\hline 0.1 & 0.01 & 100 & $2.5 \pm 0.1$ & $69 \pm 6$ & 52 & 31 & 7 & 5 & 5 \\
\hline 0.1 & 0.05 & $90 \pm 4$ & $1.9 \pm 0.2$ & $58 \pm 8$ & 66 & 23 & 4 & 3 & 4 \\
\hline 0.5 & 0 & $75 \pm 7$ & $2.9 \pm 0.4$ & $69 \pm 5$ & 40 & 39 & 19 & 1 & 1 \\
\hline 0.5 & 0.01 & $85 \pm 5$ & $2.7 \pm 0.3$ & $64 \pm 6$ & 48 & 31 & 16 & 3 & 2 \\
\hline 0.5 & 0.05 & $93 \pm 3$ & $2.4 \pm 0.2$ & $58 \pm 5$ & 66 & 20 & 9 & 2 & 3 \\
\hline 0.5 & 0.1 & $90 \pm 5$ & $2.5 \pm 0.2$ & $66 \pm 6$ & 49 & 30 & 9 & 10 & 2 \\
\hline
\end{tabular}

Table 4. Bulblet productivity in explants of non-divided scales, two- and three-divided scale-segments. \pm indicates standard error of the mean.

\begin{tabular}{lcllll}
\hline \hline Explants & $\begin{array}{l}\text { Number of } \\
\text { explants } \\
\text { cultured }\end{array}$ & $\begin{array}{l}\% \text { of } \\
\text { explants } \\
\text { forming } \\
\text { bulblets }\end{array}$ & $\begin{array}{l}\text { Number of } \\
\text { bulblets } \\
\text { per explant } \\
\text { cultured }\end{array}$ & $\begin{array}{l}\text { Number of } \\
\text { bulblets per } \\
\text { explant with } \\
\text { bulblets }\end{array}$ & $\begin{array}{l}\text { Mean fresh } \\
\text { weight of } \\
\text { bulblets } \\
\text { (mg) }\end{array}$ \\
\hline $\begin{array}{l}\text { Non-divided scales } \\
\begin{array}{l}\text { Bi-sected segments } \\
\text { basal portion }\end{array}\end{array}$ & 70 & $93 \pm 3$ & $2.7 \pm 0.2$ & $3.0 \pm 0.2$ & $81 \pm 4$ \\
$\begin{array}{l}\text { terminal portion } \\
\begin{array}{l}\text { Tri-sected segments } \\
\text { basal portion }\end{array}\end{array}$ & 75 & $69 \pm 6$ & $2.3 \pm 0.2$ & $3.4 \pm 0.3$ & $87 \pm 6$ \\
$\begin{array}{l}\text { middle portion } \\
\text { terminal portion }\end{array}$ & 65 & $39 \pm 7$ & $1.0 \pm 0.2$ & $2.6 \pm 0.3$ & $41 \pm 5$ \\
\hline
\end{tabular}




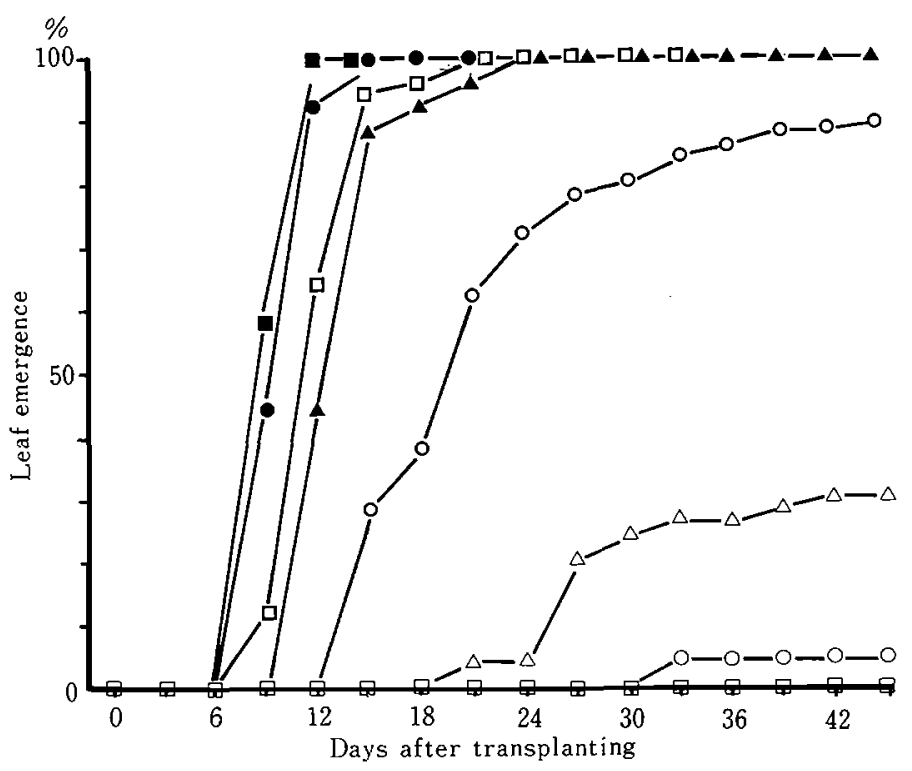

Fig. 1. Leaf emergence from bulblets of $L$. japonicum after transplanting in soil. The bulblets were stored at $4{ }^{\circ} \mathrm{C}$ for different duration, 0 ( $\square$ ). $2(\bigcirc) .4(\Delta) .6(0), 8(\Delta), 10(\bullet), 12(\square)$, and $14(\square)$ weeks, prior to the transplanting.

Table 5. Effect of different duration of cold treatment at $4^{\circ} \mathrm{C}$ on growth of bulbs after transplanting in the field. Ten bulblets. with 5 replicates for each treatment. were used. \pm indicates standard error of the mean.

\begin{tabular}{|c|c|c|c|c|}
\hline \multirow{2}{*}{$\begin{array}{l}\text { Duration of } \\
\text { treatment } \\
\text { at } 4^{\circ} \mathrm{C} \\
\text { (weeks) }\end{array}$} & \multirow{2}{*}{$\begin{array}{l}\text { Mean fresh } \\
\text { weight of } \\
\text { bulbs at } \\
\text { transplanting } \\
\text { (mg) }\end{array}$} & \multicolumn{3}{|c|}{ Bulbs harvested 13 weeks after transplanting } \\
\hline & & $\begin{array}{l}\text { Number of } \\
\text { bulbs }\end{array}$ & $\begin{array}{l}\text { Mean fresh } \\
\text { weight of } \\
\text { bulbs (mg) }\end{array}$ & $\begin{array}{l}\text { Mean fresh } \\
\text { weight of } \\
\text { roots (mg) }\end{array}$ \\
\hline 0 & $217 \pm 13$ & $8.8 \pm 0.5$ & $190 \pm 9(88)$ & $16 \pm 1$ \\
\hline 2 & $156 \pm 8$ & $9.4 \pm 0.6$ & $146 \pm 6(94)$ & $12 \pm 1$ \\
\hline 4 & $231 \pm 9$ & $9.4 \pm 0.2$ & $226 \pm 10(98)$ & $33 \pm 3$ \\
\hline 6 & $249 \pm 20$ & $8.6 \pm 0.7$ & $229 \pm 10(92)$ & $91 \pm 4$ \\
\hline 8 & $186 \pm 5$ & $9.8 \pm 0.3$ & $230 \pm 10(124)$ & $123 \pm 14$ \\
\hline 10 & $191 \pm 12$ & $9.4 \pm 0.4$ & $227 \pm 12(119)$ & $146 \pm 8$ \\
\hline 12 & $166 \pm 7$ & $10.0 \pm 0$ & $273 \pm 24(164)$ & $213 \pm 25$ \\
\hline 14 & $213 \pm 16$ & $10.0 \pm 0$ & $350 \pm 33(164)$ & $271 \pm 30$ \\
\hline
\end{tabular}

12 weeks surived. Bulblets chilled for more than 8 weeks grew, whereas those exposed to less than 8 weeks failed to grow. The prolonged chilling duration also stimulated growth of roots.

Bulblets weighing less than $100 \mathrm{mg}$ were more perishable than the heavier ones; about $50 \%$ of bulblets cultured in the light and $35 \%$ of those in the dark rotted. Among bulblets weighing more than $100 \mathrm{mg}$, fewer cultured in the dark survived. compared with those cultured in the light (Table $6)$.

In vitro light- and dark-conditions also affected some morphogenetic features of bulblets weighing more than $400 \mathrm{mg}$ at transplanting (Table 6, Fig. 
Table 6. Number of surviving bulbs and plant growth types (HTP and ETP) 8 weeks after transplanting in soil.

\begin{tabular}{|c|c|c|c|c|}
\hline \multirow{3}{*}{$\begin{array}{l}\text { Weight classes } \\
\text { of bulbs at } \\
\text { transplanting } \\
\text { (mg) }\end{array}$} & \multicolumn{4}{|c|}{ Bulblets cultured in vitro in } \\
\hline & \multicolumn{2}{|c|}{ light condition } & \multicolumn{2}{|c|}{ dark condition } \\
\hline & $\begin{array}{l}\text { Number of } \\
\text { bulblets } \\
\text { transplanted }\end{array}$ & $\begin{array}{l}\text { Number of } \\
\text { surviving } \\
\text { bulblets }^{2}\end{array}$ & $\begin{array}{l}\text { Number of } \\
\text { bulblets } \\
\text { transplanted }\end{array}$ & $\begin{array}{l}\text { Number of } \\
\text { surviving } \\
\text { bulblets }\end{array}$ \\
\hline below 100 & 89 & 43 & 46 & 30 \\
\hline $100-199$ & 32 & 32 & 22 & 14 \\
\hline $200-299$ & 17 & 15 & 11 & 3 \\
\hline $300-399$ & 15 & 15 & 5 & $2(1)$ \\
\hline $400 \sim 499$ & 7 & 7 & 6 & $4(3)$ \\
\hline $500 \sim 599$ & 2 & 2 & 6 & $4(3)$ \\
\hline above 599 & 2 & $2(1)^{y}$ & 12 & $12(12)$ \\
\hline
\end{tabular}

2). Nearly all bulblets that had been cultured in the dark developed into epigeous type plants with elongated axes (ETP), while the bulblets that had been incubated in the light grew only scaly leaves, or had hypogeous growth habit (HTP), except one bulblet that developed an elongated axis. The plantlets with elongated axes required at least 2 years' cultivation in soil before they flowered (Fig. $3)$.

\section{Discussion}

\section{Choosing initial propagation-materials}

Using higher regenerative and pathogen-free tissue materials is essential in in vitro vegetative propagation. Robb (1957) reported that in vitro scale-segment culture is useful for the proliferation of bulblets of $L$. speciosum. Many experiments have used bulb-scales as very old common practice in the in vitro vegetative propagation of Lilium species. My data confirm that scale-segments possess the highest regeneration capacity among explants, but the highest incidence of contamination occurs in spite of careful sterilization (Table 1). This phenomenon was also observed in L. rubellum (Niimi and Onozawa, 1977) and Ornithogalum (Nel, 1981). Young leaf-explants of L. japonicum are easily sterilized and the explants form as many bulblets as bulb-scale segments. This is consistent with the previous results that young leaf-strips of several Lilium species have high regeneration potential and are among the most reliable sources for in vitro propagation of Lilium (Niimi, 1986). Thus, young leaf-strips were chosen as initial propagation-materials to establish a system of aseptic tissue culture of L. japonicum .

There were clear differences in the regeneration potential of the leaf-segments (Table 2) and scalesegments (Table 4) of L. japonicum. Strips excised from the basal portion of each organ had higher regenerative capacity than did the others. The low regeneration capacity of GL-II can be improved to a certain extent by modifying the concentration of NAA and BA (Table 2) which is consistent with previous results (Niimi, 1986). Van Aartrijk and Blom-Barnhoorn (1981) showed that BA does not increase the number of bulblets in the bulb-scale cultures of $L$. speciosum. The effect of BA on the formation of plantlets may be partially due to the differences in the physiological or ontogenetic ages of leaves and scales.

\section{Proliferation of bulblets}

The addition of NAA, or BA, or both at different concentrations to the medium has insignificant effects on increasing the number of bulblets per scale or on improving the growth of generated bulblets (Table 3 ). Similar results were obtained with L. rubellum (Niimi, 1985) and L. longiflonum (Stimart and Asher, 1978). In these lilies auxins 


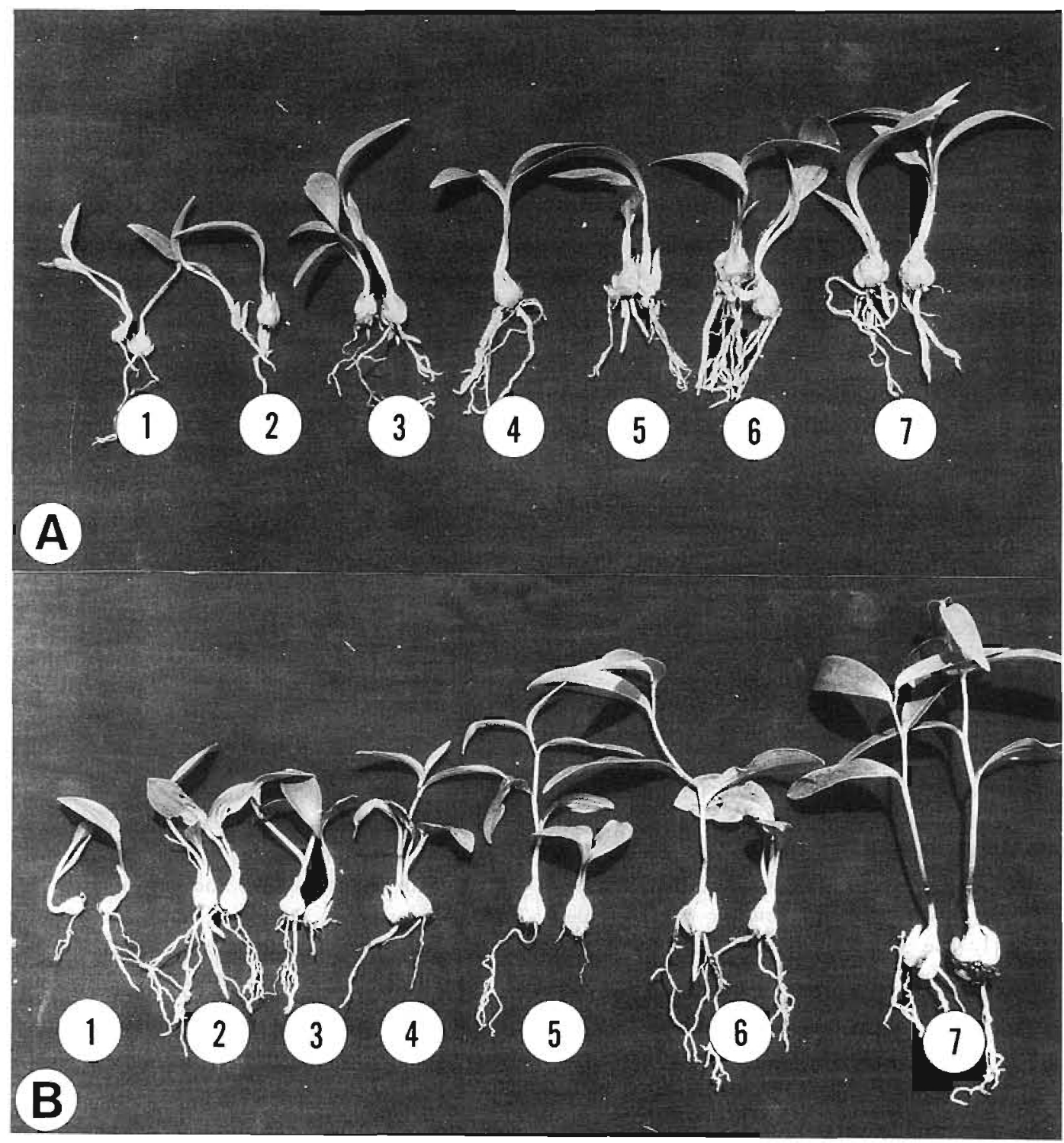

Fig. 2. Post-in vitro development of L. japonicum bulblets. (A) unbolted bulblets (hypogeous type plant; HTP) cultured in the light. (B) bolted bulblets (epigeous type growth; ETP) cultured in the dark.

The weight of bulblets at transplanting were as follows; 1, less than $100 \mathrm{mg} ; 2,100 \sim 199 \mathrm{mg} ; 3,200 \sim 299$ mg; 4, 300 - 399 mg; 5, 400 - 499 mg; 6. 500 -599 mg; 7. above $599 \mathrm{mg}$.

at low concentration are suitable for the regeneration and growth of bulblets, whereas cytokinins are ineffective. The genus Lilium is known to have a high capacity to generate bulblets through in vivo scale propagation, or scaling. Based on these results it was decided that the addition of 0.05 and $0.1 \mathrm{mg} \cdot$ liter $^{-1}$ NAA only or $0.1 \mathrm{mg} \cdot$ liter $^{-1}$
NAA in combination with $0.01 \mathrm{mg} \cdot$ liter $^{-1} \mathrm{BA}$ to the basal medium was the optimum condition for the regeneration of bulblets in the scale cultures.

A method of culturing bi- or tri-sectioned scalesegments had little effect on increasing the number of bulblets (Table 4), because segments excised from terminal- and middle-portions of a scale had 


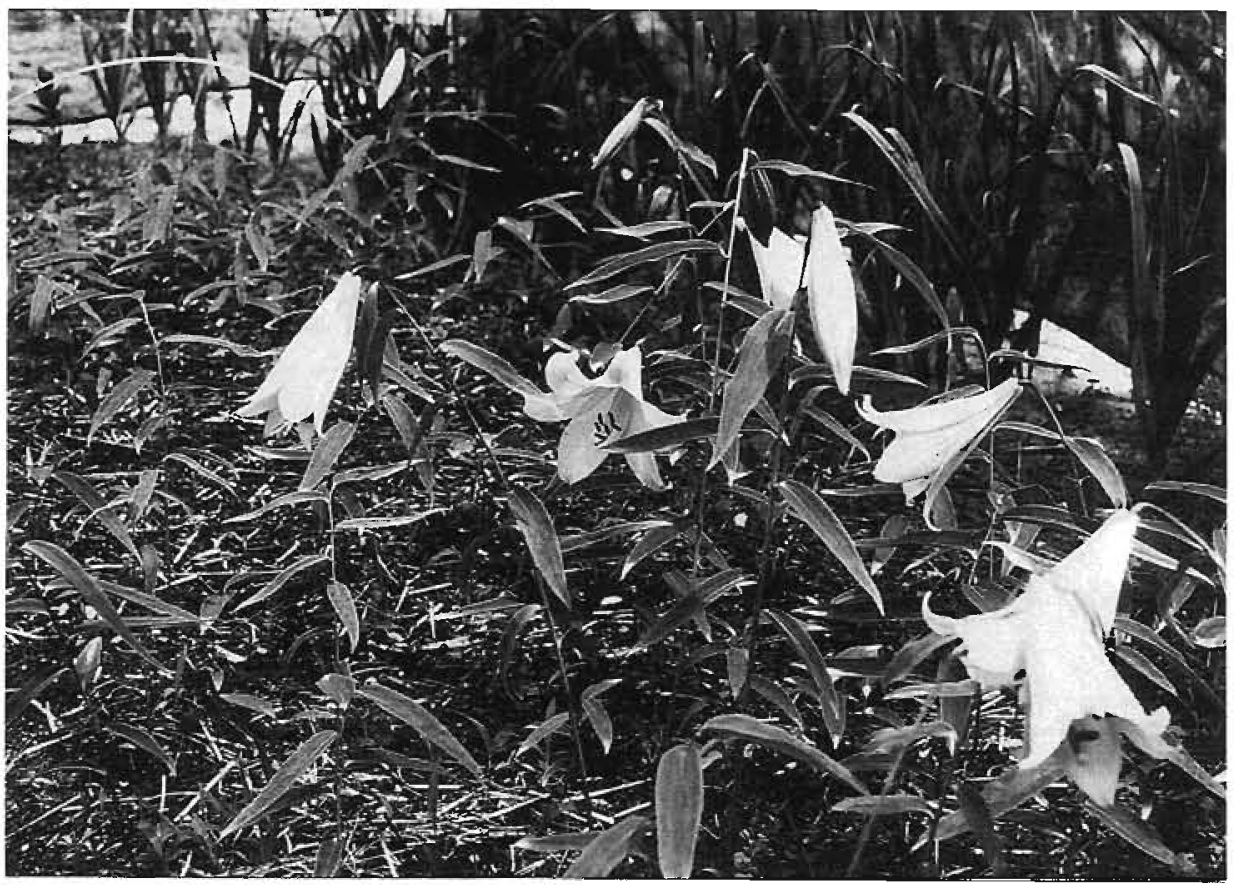

Fig. 3. L. japonicum flowering in the third spring after transplanting.

low regeneration potential, compared with the basal segment and a whole scale. In the in vitro proliferation of L. japonicum, Asao et al. (1992) reported that, like a whole scale, each of the four individual segments excised from a whole scale forms nearly the same number of bulblets. This discrepancy probably results from the differences in the physiological conditions of cultured ex. plants.

\section{Establishment in soil}

A cold treatment of more than 12 weeks broke the dormancy of bulblets of L. japonicum (Fig. 1) and accelerated the growth of each organ (Table 5). This response is comparable to those of $L$. nubellum (Niimi, 1988) and L. speciosum (De Klerk et al., 1992), which demonstrated that bulblets require a cold treatment at $4{ }^{\circ} \mathrm{C}$ for at least 8 weeks before the bulblets transplanted into soil. Therefore, the cold treatment of bulblets is one of the essential treatments for post-in vitro establishment of most Lilium species.

Table 6 shows that there may be two factors responsible for bulblet-rot infection in soil: 1) small bulblets of $L$. japonicum, weighing less than 100 $\mathrm{mg}$, are more perishable in soil than are larger ones, implying that smaller bulblets have a lower degree of resistance to pathogen attack as com. pared with larger ones; and 2) light probably makes the outer scales of bulblets physically tough, resulting in imparting some tolerance to moisture stress and a resistance to certain pathogens.

Bulblets cultured in the dark, weighing more than $400 \mathrm{mg}$ at the time of transplanting developed elongated axes (Table 6), which indicates that not only the sizes of bulblets but the light also modified the developmental morphology of the plants. Thus, dark condition which favors ETP instead of HTP may be more suitable for commercial bulb production because ETP plants seem to be more photosynthetically efficient than HTP ones. Therefore, it is recommended that bulblets are cultured in the dark until they weigh more than 400 $\mathrm{mg}$ and subsequently cultured in the light for a few weeks before transplanting into soil.

\section{Literature Cited}

Asao, H., S. Matutani, K. Tanaka and S. Arai. 1992. Micropropagation of Lilium japonicum Thunb. by 
scale culture. Bull. Nara Agri. Exp. Sta. $23: 1-6$. (In Japanese with English summary).

De Klerk, G. J., I. Delvallee and A. Paffen. 1992. Dormancy release of micropropagated bulblets of Lilium speciosum after long culture in soil. HortScience 27 : 147-148.

Matsuo, E., K. Arisumi and H. Kawashima. 1982. Cultural practices influencing premature daughter leaf and/or shoot emergence in scale-propagated Easter lily. HortScience 17 : 196-198.

Murashige, T. and F. Skoog. 1962. A revised medium for rapid growth and bioassays with tobacco tissue cultures. Physiol. Plant. 15 : 473-497.

Nel, D. D. 1981. Rapid propagation of Omithogalum hybrid in vitro. Agroplantae $13: 83-84$.

Niimi, Y. 1985. Factors affecting the regeneration and growth of bulblets in bulb-scale cultures of Lilinm nubellum Baker. J. Japan. Soc. Hort. Sci. 54 : $82-86$

Niimi, Y. 1986. Application of leaf-segment cultures to in vitro bulblet production of six Lilium species. Acta Bot. Neerl. 35 : 189-194.

Niimi, Y., Y. Endo and E. Arisaka. 1988. Effects of chilling-and $\mathrm{GA}_{3}$-treatments on breaking dormancy in Lilium nubellum Baker bulblets cultured in vitro. J. Japan. Soc. Hort. Sci. $57: 250^{-257}$. (In
Japanese with English summary)

Niimi, Y. and T. Onozawa. 1977. Vegetative propagation of L. rubellum Baker; comparison of bulblet formation between scaling and scale-segments cultured in vitro. Abstr. Japan. Soc. Hort. Sci. Autumn Meet: 348-349. (In Japanese).

Niimi, Y. and T. Onozawa. 1979. In vitro bulblet formation from leaf segments of lilies, especially Lilium mbellum Baker. Scientia Hortic. 11 : 379-389.

Robb. S. M. 1957. The culture of excised tissue from bulb scales of Lilizm speciosum Thunb. J. exp. Bot. $8: 348-352$.

Shimizu, M. 1987. Lilium japonicum Thunb. p. 53-59: In M. Shimizu (ed.). The lilies of Japan, Species and Hybrids. Seibundo Shinkou-sha, Tokyo. (In Japanese).

Stimart, D. P. and P. D. Ascher. 1978. Tissue culture of bulb scale sections for asexial propagation of Lilium longiflorum Thunb. J. Amer. Soc. Hort. Sci. 103: 182-184.

Van Aartrijk, J. and G. J. Blom-Barnhoorn. 1981. Growth regulator requirements for adventitious regeneration from Lilium bulb-scale tissue in vitro, in relation to duration of bulb storage and cultivar. Scientia Hortic. 14 : 261-268. 


\title{
ササユリの試験管内増殖と阑場への移植
}

\author{
新美芳二 \\ 新潟大学宸学部 950-21 新潟市五十嵐 20町
}

\begin{abstract}
摘要
萌芽間もない开サユリの母球を堀り上げ，組織培盖 による增殖と形成された子球の移植条件について調べ た。

1．母植物を実験围場より採集し，りん茎，未展開 葉，荎に分噍した、りん片拉よび葉ではその基部付近， 茎では先端部分から外植体を調整し，それらを Murashige · Skoog (1962)の無機塩培地と数種類の有 機物，し上糖を含む基本培地にNAA $1.0 \mathrm{mg} \cdot$ liter $^{-1}$, BA 0.1 mg・liter ${ }^{-1}$ 添加した培地で培養した。

各外随体の子球形成数, 子球重抢上び污染率の結果 から，初代培善の外植体として葉切片がよいことがわ かった：また，葉切片の子球形成はNAA 0.5 mg $\cdot$ liter $^{-1}$, BA $0.05 \mathrm{mg} \cdot$ liter $^{-1}$ の添加で促進されることもわかっ た.

2. 無菌培養中の子球から分踓したりん片を培盖し た結果，これらのりん片からの子球の形成および成長 にはNAA $0.1 \mathrm{mg} \cdot 1$ liter ${ }^{-1}$, BA $0.01 \mathrm{mg} \cdot 1$ iter $^{-1}$ が適し

ためにりん片を分割して培盖したが，りん片当たりの 子球数の增加はわずかであった。

3. 出葉開始時期, 最終出菜率, 子球と根の生長扝 よび子球の简敗率の結果から, 試験管内で培養した子 球を圈場に移植する前に 12 週間の $4{ }^{\circ} \mathrm{C}$ での低温処理 が必要であることがわかった。

4. 國場への移植時に $100 \mathrm{mg}$ 未満の子球は培養期 間中の明・暗条件に関係なく腐敗しやすく, $100 \mathrm{mg}$ 以上の子球でも暗条件下で培涪した子球は明条件下で 培盖したものと比へ應敗する子球が多かった。

5. 移植時に $300 \mathrm{mg}$ 未满の子球は培養中の光環境 条件で関係なくすべて地中型植物（HTP）となった. 試験管内で $400 \mathrm{mg}$ 以上に生長した子球では，明条件 で培養した子球はほとんど地中型植物であったが，暗 条件のものはほとんどすべて地上型植物（ETP）とな った。これら地上型植物が開花するまでには少なくと も2 年間の娄場での栽培を必要とした。
\end{abstract} ていた、またりん片当たりの子球形成数を增加させる 